\title{
ORHAN KAPLAN
}

\section{Son Dönem Osmanlı Müelliflerinden Roma Sefareti İmamı Hâşim Veli'nin Mevlid Şerhi: "Esrâr-ı Mevlidü'n-Nebî"}

\author{
One of the Last Period Ottoman Authors and Rome \\ Embassy Imam Haşim Veli's Mawlid Paraphrase: 'Birth \\ Mystery of Last Prophet /Muhammed Mustafa'
}

Ö Z E T

Anadolu coğrafyasında Hz. Peygamber'e duyulan sevgiyi şiir kalıbı içerisinde sunabilmiş nadir eserlerden biri Süleyman Çelebi'nin Vesiletü'n Necât adl eseridir. Bilinen adıyla Mevlid, her yüzyılda büyük bir sevgiyle okunup özel günlerin ve kutsal gecelerin vazgeçilmez bir geleneği haline gelmiştir. Gönüllere tercüman olan bu eser aynı zamanda Sehl-i Mümteni'nin orijinal bir örneğ $i$ sayllmaktadır.

Esere çeşitli dönemlerde bazı şerhler yazılmıştır. Bu şerhlerden biri de hayatı hakkında fazla bilgiye sahip olmadığımız Roma sefareti imamı Hâşsim Veli'nin "Esrâr-ı Mevlidü'n Nebî" adlı eseridir. Bu çalışmada Hâş̧im Veli'nin Mevlid Şerhi, Latin harflerine aktarılmış ve eser üzerinde genel bir değerlendirme yapılmıştır.

A N A H T A R KELİMELER

Hâşim Veli, Süleyman Çelebi, Mevlid şerhi.
A B S T R A C T

Süleyman Celebi's work which is called Vesiletü'n Nejat is one of the most uncommon work, which represents the pure love to Muhammed Mustafa (last Prophet) with a poem verse in Anatolian Region/geography. With its common name 'Mawlid', which was read with a big fancy in every century, has become indispensable tradition of Holy nights and special days. This work, which articulates minds and hearts, is accepted as one of the original sample of 'Sehl-i Mümteni'.

Some paraphrases were written to the work in various periods. One of these was the work of Rome Embassy Haşim Veli, about whom we do not know a lot of things, called 'Birth Mystery of Last Prophet /Muhammed Mustafa'. In this study, Haşim Veli's Mawlid paraphrase has been translated into the Latin characters and a general evaluation has been done on the composition.

$$
\text { K E Y W O R D S }
$$

Haşim Veli, Süleyman Çelebi, Mevlid şerhi.

\section{Giriş}

Hz. Peygamber'in doğumuyla ilgili manzum ve mensur eserlerin genel adı olan Mevlid, daha ziyâde mesnevi nazım şekliyle yazılmış olan

\footnotetext{
Arş. Gör. Sakarya Üniversitesi, Fen-Edebiyat Fakültesi Türk Dili ve Edebiyatı Bölümü, (okaplan@sakarya.edu.tr).
} 
eserlerdir. Mevlidlerde, Hz. Peygamber'in doğumu [velâdet], peygamber oluşu [risâlet], göğe yükselişi [mi'râc] ve vefatı [rihlet] gibi konular işlenmektedir. "Aruzun remel bahrinde "fâilâtün/fâilâtün/fâilâtün/ fâilün kalıbıyla, bölümler arasında geçişi sağlamak üzere tekrarlanan vasıta beyitleriyle ve geleneğin estetik nizâmına bağlı olarak ses benzerliğinden çok harf benzerliğine dayanan göz kafiyesi anlayışıyla yazılan" (Eroğlu 2010: 109-125) bu eserler daha çok Hz. Peygamber'in doğum günü dolayısıyla yapılan merasimlerde okunma gayesiyle oluşturulmuştur.

Mevlid törenlerinin ortaya çıkışı ile ilgili kesin bilgiler olmamakla beraber "tarih içinde İslâm âleminde ilk defa Mısır'da Fâtımiler devrinde [m. 910-1171] Hz. Peygamber'in doğum gününü kutlamak için tören yapıldığı tespit edilmektedir. Hz. Peygamber, zamanında böyle bir şenlik yaptırmadığı gibi, ondan sonra Dört Halife, Emeviler ve Abbasiler zamanında da bu şekilde merasimler yapılmamış, Fâtımiler devrinden günümüze ise herhangi bir eser ulaşmamıştır. Şöhreti dolayısıyla son zamanlara kadar mevlid konusunda bilinen ilk eser olarak, hadis bilgini İbni Dihye'nin [ö. m. 1235] Kitâbü-t-Tenvîr fi Mevlid-is-Sirâc-il-Münir'i kabul edilmiştir. Daha sonraları Süleyman Çelebi'ye kadar çok sayıda Arapça mevlid kaleme alınmış, İran edebiyatında ise mevlid yazılmamıştır." (Timurtaş 1980: IV)

Sosyolojik ve kültürel açıdan bakıldığında İslâm tarihine ait bir olayın edebiyat sahasına taşınması geniş halk kitleleri tarafından bu metinlere farklı bir gözle bakılmasını sağlamıştır. İnancın sanatla birleşmesi bu eserlere uhrevî bir hava katarken zaman içerisinde bu eserlere kutsiyet de atfedilmiştir. İslam coğrafyası içinde bu tarz eserlerin en fazla Anadolu'da verilmiş olması da bu topraklarda Hz. Peygamber'e duyulan sevginin somut göstergesi olarak düşünülebilir. "Illk olarak Ahmedî'nin İskendernâmesi'nin bir nüshasında görülen mevlidin" (Köksal 2009:15) daha sonra "yaklaşık 200'e ulaşması" (Aksoy 2004: 482) da bu türe olan ilgiyi göstermektedir.

15. yüzyılda Süleyman Çelebi tarafından yazılan mevlid ise etkisi günümüzde bile devam eden en güzel mevlid örneklerinden biri olarak kabul edilmektedir. Zaman içinde özel günlerin ve kutsal gecelerin vazgeçilmez dinî ritüeli hâline dönüşen bu eser, sahip olduğu dil ve ifade 
hususiyetleri ile edebiyat tarihinin şâheserlerinden biri olmuştur. Köprülü'nün eser hakkında yaptığı şu değerlendirme de çoğu araştırmacının benimsediği ortak bir yargı hâline dönüşmüştür: "Halk arasında okunmaya mahsus siyer kitaplarının en güzelini Süleyman Çelebi 812'de Bursa'da yazdi. Onun Mevlid manzûmesi asırlarca halk arasında okundu, hatta bestekârlar tarafından bestelendi. Her asırda ona birçok nazîre yazıldığı hâlde, ifadesindeki sadelik ve selâset, şâirin ilhâmındaki samimilik ve tabiîlik, onu Türk edebiyatının bir şâheseri hâlinde asırlarca yaşattı." (Köprülü 2003: 372) Eserin büyüklügüu, sahip olduğu sanatsal değerin ötesinde sosyal hayatın bir parçası olmasıyla daha da kuvvetlenmiş ve haklı bir şöhrete kavuşmuştur. Bir metni açıklamak için yazılan şerhlerin, daha çok kiymetli eserlerden seçilmesi ve Mevlid üzerine de şerhler yazılması, eserin büyüklügünü gösteren başka bir delil olarak düşünülebilir.

“Eser üzerine özellikle 19. ve 20. yüzyıllarda şerhler yazılmıştır. Bunun başlıca sebepleri, eserin bir kısmının mevlid meclislerinde sürekli okunarak hemen herkes tarafından bilinir hâle gelmesi ve bunun sonucunda layıkıyla anlaşılması ihtiyacının doğması, içerisinde dinîtasavvufî birtakım manalar barındırması ve hem Hz. Peygamber'e duyulan derin sevginin hem de Süleyman Çelebi'ye gösterilen sonsuz hürmetin ifadesinde aracı konumda olmasıdır. Çoğu müellif Mevlid'e nazire yazarak bu duygu yoğunluğunu gösterirken bazı kalem erbâbı da eseri şerh etmek suretiyle hüner göstermişlerdir." (Yılmaz 2011: 34) Yazılan bu şerhler, eserin sahip olduğu dil, anlam, sanat ve estetik değerinin daha iyi anlaşılmasına yardımcı olmuştur. Esrâr-ı Mevlidü'n-Nebî́nin mukaddime bölümünde Haşim Veli'nin belirttiği gibi Süleyman Çelebi sözü az, manası çok, düzgün ve akıcı bir ifade ile sade bir eser ortaya koymuştur. Buna rağmen eser, ayet-i kerime ve hadis-i şerifler başta olmak üzere dinî unsurlara yapılan göndermelerin sonucu olarak yoğun bir anlatıma sahiptir. Bu yoğun anlatım şerhler sayesinde görünür k1lınmış, eserin değerini artıran anlam örgüleri ortaya çıkarılmıştır. Bu şekilde Süleyman Çelebi'nin Mevlid'ine yapılan şerhlerden bazıları şunlardir: 
“Gülzâr-ı Aşk: Hüseyin Vassâf tarafından kaleme alınmıştır. Mustafa Tatçı, Musa Yıldız, Kaplan Üstüner tarafından Latin harflerine aktarılmıştır. En hacimli mevlid şerhidir.

İzâhü'1 Merâm Alâ-Vilâdeti Seyyidi'1-Enâm: Cabbarzâde Mehmed Arif Bey tarafından yazılan eser Latin harflerine aktarılmış ve eser üzerinde bir inceleme yapılmıştır. ${ }^{1}$

Şerh-i Mevlid-i Şerîf: Milli Kütüphane Yazmalar Koleksiyonu 578 numarada kayıtlı eserin müellifi bilinmemektedir. 40 varak ve 9 satırdan oluşan bir risaledir.

Esrâr-1 Mevlidü'n Nebi: Roma Sefareti İmamı Hâşim Veli tarafından 1326'da İstanbul Karagöz Matbaası'nda basılmış 22 varaklık küçük bir şerhtir." (Y1lmaz 2011: 35)

\section{Hâşim Veli'nin Eserleri}

Hayatı hakkında fazla bilgiye ulaşamadığımız Hâşim Veli'nin kütüphane ve katalog taramaları neticesinde ulaştığımız kendisine ait yazıları ile bastırmış olduğu eserler şunlardan oluşmaktadır.

Atalar Sözü: Çok sayıda atasözü ve deyimin yer aldığı kitap üzerine bir çalışma yapılmıştır. ${ }^{2}$ Eserde Kuzey ve Güney Türklerine ait çok sayıda atasözü ve deyim bulunmaktadır. Kitabın sonunda da bilmecelere yer verilmiştir. (Küçük 2010: 141-176) Hâşim Veli, eserin önsözünde Türk dilini öğrenmek isteyenlere hizmet olacağı düşüncesiyle atasözlerinden bir miktar topladığını belirtmektedir. [Yayın Yılı: 1926, Dil: Türkçe, Kütüphane: Ankara - İlahiyat Fak., Atatürk-Merkez, AYK - Atatürk Kültür Merkezi, AYK-Türk Tarih Kurumu, Bilkent-Merkez]

Tercümeli Yâsin-i Şerîf: İstanbul Kırmızı Ziya Efendi Matbaası'nda basılan eserde, Yasin suresi kelimesi kelimesine ve manaları verilerek

\footnotetext{
${ }^{1}$ İzâhü'1 Merâm Alâ-Vilâdet-i Seyyidi'l-Enâm: Cabbarzâde Mehmed Arif Bey, bk. YILMAZ.

2 Türk Dünyasından Derlenmiş Bir 'Atalar Sözü' Kitabı, Murat Küçük, Modern Türklük Araştırmaları Dergisi, 7/1: 141-176.
} 
tercüme edilmiştir. [Yayın Yılı: $\quad$ 1932, Dil: Türkçe, Kütüphane:

Milli Kütüphane, AYK - Türk Tarih Kurumu, Kültür Ve Turizm - Ankara Adnan Ötüken İHK.]

Tercümeli Âmme Cüzü: Yayın Yılı: 1927, Dil: Arapça, Kütüphane: Ankara - DTCF.

Efsâh ul-Makâl Fi'1-Mesîhi'd-Deccâl: Kamil Çakın tarafından sadeleştirilen eser, âyet ve hadislerin batinî yorumlamalar suretiyle siyasi alanda nasıl kullanıldığına örnek teşkil etmesi bakımından önem taş1maktadır. (Çakın 2003: 183-198) [Yayın Yılı: 1913, Dil: Arapça, Kütüphane: Ankara - DTCF]

Kuran-1 Kerim'in Tercümesinden Bir Numune: Ve'd-duha Suresinden Nas Suresine kadar olan bazı surelerin tercümesi ve İhlâs suresinin de kısaca mealinin olduğu eserdir. [Yayın Y1lı: 1339, Dil: Türkçe, Kütüphane: Ankara - Dil Tar.Coğ.Fak.]

Makamât-1 Harirî Tercemesi: [Yayın Y1lı: 1326, Kütüphane: AYK Atatürk Kültür Merkezi]

Makalât: Bir Gazel-i Sufiyanenin İzâhı: [Yayın Yılı: 17 Mart 1332, Dil: Türkçe, Kütüphane: Milli Kütüphane]

Felsefe:Levâmi: [Yayın Yılı: 26 Kanunusani 1331, Dil: Türkçe, Kütüphane: Milli Kütüphane]

Vatikan Kütüphanesinde Âsâr-1 İslâmiyye: [Yayın Yı1ı: 27 Rebiyülahir 1329, Dil: Türkçe, Kütüphane: Milli Kütüphane]

Tarîkat-i Mevlânâdan: [Yayın Y1lı: 28 Kanunuevvel 1331, Dil: Türkçe, Kütüphane: Milli Kütüphane]

Kitab-1 Mesnevî: [Yayın Yıll: 22 Kanunuevvel 1332, Dil: Türkçe, Kütüphane: Milli Kütüphane] 


\section{Metin}

[1]

Esrār-1 Mevlidǖn-Nebīi

Şāriḥi:

Romā Sefāret-i Seniyyesi İmamı

Hāşim Velì

Karagöz Maṭba'ası, Bāb-ı 'Ālì Caddesi, numara: 44

Sene 1320 
[2]

Muḳaddime

'Ālem-i İslāmda şöhreti müstaġnì'-i ìżāh olan Mevlidü'n-Nebī 'aleyhi'ṣșalātü ve's-selām risāle-i manzūumesi 'uşşāk-1 Resūlullāhdan Süleymān Çelebì Hażretleriniñ eșer-i 'aşkları olub müşārün-ileyh bu eșer-i mübeccelde mebde-i hilḳatden ve nūr-1 Muhammedīden ve vilādet-i nebeviyyeden muhtașar ve mücmel faḳat gàayet selīs ve ma'nīdār olaraḳ baḥs ve fahru'lmürselīn, imāmü'l-müttaḳin ḥażretleriniñ terceme-i hālini ifādede bir fihristi mükemmel ü āli tanzịim buyurdular ve bu șūretle erbāb-1 hakịiḳati kendilerine minnetdār eylediler.

Mevlid-i Şerīf ol derece 'ālìdir ki mevżūí hakạiḳat-i Muhammediyye, aḥkāmı tezkiye-i nefs ve gāayeti 'aşḳ, fā’idesi istirāḥat-ı vicdāndır.

Müşārün-ileyh ḥażretleriniñ ifāde ve işāret buyurduḳları mevżū'ı fehm etmek kelime-i nefsini 'illet-i cehl ü ināddan tahliye ve muhabbet-i Āl-i resūl ile tahliye itmege vā-bestedir.

Muhibleri de bu yolda Mevlīd-i Şerífi ḳırāat ve istimāe eden ihvāna yādigār olmak üzere, ūşşāḳ-1 Resūlullāhıñ rūḥāniyyetinden istimdād ederek yazdig̀ım şu eșeri kendilerine taḳdīm ediyorum.

Hāşim Velī 
[3]

\section{Bismillāḥirraḥmāni'rrāḥim}

'Uşşāḳ-1 Resūlullāhdan Süleymān Çelebī hażretleri Mevlidü'n-Nebī 'aleyhi'ṣ-ṣalātü ve's-selām nāmındaki eșer-i 'ālīlerinde:

Allāh adın żikr idelüm evvelā

Vācib oldur cümle işde her ḳula

ḳıta'sıyla bed' buyurub her işde ism-i pāk-i Subhāniyyeniñ żikri vācib oldugunu tașrịh ediyorlar.

Allāh adın her kim ol evvel ana

Her işi āsān ider Allāh ana

şu beyt-i şerīf irā'e ediyor ki ism-i celîl-i Subḥānī ile bed' olunan iş ne ḳadar zor olursa olsun suhūlete münḳalib olur. Her şey meşiyyet-i Subhāniyye ile ḥuṣūl bulduğunu ve kāìnātda mümkinü'l-ḥuṣūl her şey'iñ vuḳū' bulması himmete vā-beste olduginu anlayan kimse

"همة الر جال تقلع الجبال، mażmūnunca ḳudret-i 'abd ḳudretullāha istinād etdikce her şe’yiñ āsān olacaġını bilir.

Allāh adı olsa her işiñ öñi

Hergiz ebter olmaya anuñ șoñı

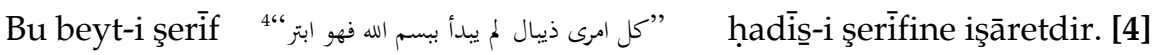

Her nefesde Allāh adın di müdām

Allāh adiyla olur her iş tamām

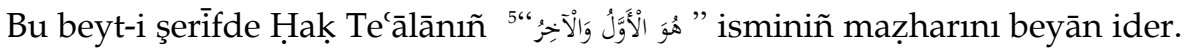
Bir kimse ki tevḥidullāhda rabṭ-1 ḳalb ederse her nefesi Allāh adına muḳāin olur. Bu cihetle o kimse bir işiñ gerek bidāyet, gerek nihāyetinde zikri ve fikri Allāh adı olur.

3 himmet-ür-ricâl, takla'-ül-cibâl [becerikli insanların himmeti, dağları yerinden söker]

${ }^{4}$ Allah'ın adıyla başlatılmayan hiçbir işte hayır ve bereket yoktur. [el-Aclûnî, Keşfü'lHafâ, C. II, s. 109]

${ }^{5} \mathrm{O}$ ilktir, sondur. Hadîd/3 
Bir kez Allāh dise şevḳıla lisān

Dökilür cümle günāh missl-i hazān

beyiti ile ifāde buyuruyorlar ki ma'āṣî ve seyyi'ātıñ maḥv u münderis olması içün ism-i celīl-i Subḥāniyi żikrde 'aşk u şevḳe muḳārenet şarțdır. Bu gibi 'uşşāḳ-1 ilāhiyyeniñ kendileri żāt-ı ahadiyyetleri gibi pāk olur. Binā'en'-aleyh irāde-i 'abd, irāde-i ilāhiyyeye muvaffak olmag̉la her murāda erer.

'Uşşāḳ-1 șādıḳa 'ālemü'ş-şuhūdda birțaḳım taḳayyüdāt-ı țabíiiyye ile muhtecib olmak havfından gözleri yaşlı ve derūnları derdli olur. Bunlar Raḥmān ṣıfat-ı celīlesine maẓhar olduḳlarından cemí'i maḩlūḳāta şefḳat ve merḥamet anlarıñ hașāi'ṣ-i lāzımesindendir.

Birdür ol birligine şek yoḳ durur

Gerçi yañlış söyliyenler çoḳ durur

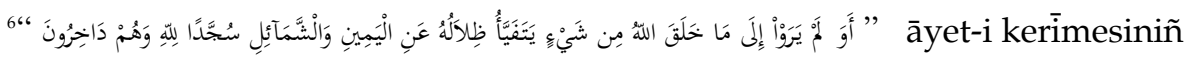
dahi delālet buyurdugiu vechile márifetullāhda gāafiller her ne kadar lisānlarıyla yañlış söyleseler ve bāb-1 ulūhiyyetde üçdür beşdir deseler de lisān-1 ḥālleri şübhesiz żāt-1 ulūhiyyetiñ ancaḳ bir oldug̉una açıḳca şehādet etmekdedir.

Cümle 'ālem yoġıken ol var idi

Yaradılmışdan ganī cebbār idi

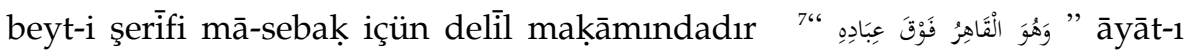
kerimeleri muḳteżā-yı münífleri vechile ceberūt-1 Subḥāniyye [5] ve saṭvet-i ilāhiyye ḳarşısında her şey zelīil, faḳīr ve 'āciz, muțīolub hiçbir kimsede ḳānūn-1 ilāhiyyeniñ hāaricine çıkmag̉a țāḳat yoḳdur. Binā'en-'aleyh aḥadiyyet ve vaḥdāniyyeti cemi'-i mahlūḳāt țav'an ve kerhen iḳrār etmekdedir. Anın içün:

\footnotetext{
${ }^{6}$ Allâh'ın yarattığı herhangi bir şeyi görmediler mi? Onun gölgeleri, küçülerek ve Allah'a secde ederek sağa sola döner. Nahl/48 [Yani gölgesi bulunan eşyanın gölgeleri bile sahiplerinin hükmünde değil, Allah'ın emri altındadır. Sahibi ne kadar uğraşırsa uğraşsın, gölge Allahu Teâla'nın emri ve takdiri doğrultusunda 1şığın geldiği noktaya ters istikâmette düşer ve onun değişmesini takip eder. Aynı zamanda gölge 1şığın bir eseri de değildir. Ancak Allah'ın bir kanunu gereğidir. Dolayısıyla eşyanın gölgelerinde bile hüküm ve tasarruf Allah'ındır.] (KuranKerim ve Açıklamalı Meâli, TDV Yay. s. 271)

${ }^{7} \mathrm{O}$, kullarının üstünde her türlü tasarrufa sahibidir. $\mathrm{O}$, hüküm ve hikmet sahibidir, her şeyden haberdardır. Enam/18
} 


\section{Șun'ila bunları ol var eyledi \\ Birligine cümle iḳrār eyledi}

beyitini terdīf buyurdular. Sāḥa-ārā-yı şuhūd olan her şeyde ḳudret-i rabbāniyyeniñ āșārı ve kemāl-i șun'ı görülmektedir. Gözlüye gizli yoḳdur.

Bu derecede kemālāt-1 Subhāniyyeyi bilenler " "الاهو" dirler. Fi'lvāḳı'vaḥdet-i șubhāniyyeyi muṭlaḳā iḳrārda kāffe-i mahlūḳāt müşterek ise de 'irfān ve yaḳin ile Hak Subhānehû ve Tecālā hażretleriniñ vaḥdetini iḳrār ancak ehlullāha maḥṣuṣ̣dur.

Şu mebde'de müşārün-ileyh nāẓm hażretleri tọkuz dane Allāh ism-i celīl-i Subhāniyyesini zikr buyurarak țoḳuz 'adedi de müntehā-yı 'aded olmag̉la zāàt-1 Allāhu Te'ālā ve teḳaddesiñ nā-mütenāhī ve șun'-1 ilāhîisiniñ lā-yu'ad ve lā-yuḥ̣a olduguna işāret buyurdular. Ba'dehû ba'ż-1 ṣıfāt-1 ilāhiyyeyi beyān edüb buña dahi hạadd u nihāyet olmadığı cihetle:

Bari ne hạâcet ḳılāvuz sözi çok

Birdir Ol kim andan artık Tañrı yok

diyerek mecmū'ına dā’ir ḥācet mess etdirerek sıfāt-ı ilāhiyyeyi ta'dād edecek

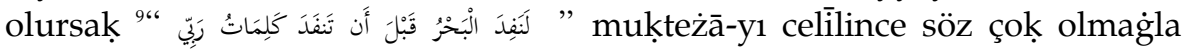
beraber nihāyet bulmaz demekdir. Lisān-1 Türki'de "bari ne" kelimesi hepsine, mecmū'ina, kāffesine demekdir. Ya'ni hālikiyyet-i subhāniyyeye dā'ir hạācet miḳdārı ve kifāyet derece söyleyecek olursak bu bābda söz ve kelām çoḳdur. Bināberīn degil şu mecmūa', kāffe-i kütüb bile anı derece-i iḥtiyācda şerḥ ve îżāḥa ġayr-1 kāfīidir. Yāhuūd "bari" kelimesi hulāṣa'-i kelām ma'nāsına olub yine de ma'nā-yı meşrūh melhụuzdur. Binā'en-'āleyh "Birdir Ol kim andan artuk Tañrı yoḳ" buyurarak hatm-i kelām ediyorlar. "Ol" lisān-1 Türkì'de "Hū" ism-i celīliniñ mürādifidir. Çünki "Hüve'l-bākī "dir.

Ey 'azīzler işde başlaruz söze

Bir vașiyet ḳılavuz illā size

[6] buyurmaları mevlīd-i şerífi istimā' edenleriñ ecizze ü sādāt-ı kirāmdan olmalarına işāretdir. Zîrā böyle nādirü'l-vücūd e'izze-i kirāmdan mā'adā birṭaḳım maḥcūbì mevlid-i şerifden ne ḥaẓ alabilir.

Nūr-1 ḥażret-i fahru'l-mürselīni beyān șadedinde 'ālemiñ zuhūruna sebeb-i yegāne olarak:

\footnotetext{
${ }^{8}$ Ondan başka ilâh yoktur.

${ }^{9}$ Rabbimin sözleri bitmeden önce denizler tükenecektir. Kehf/109
} 
Muṣtafa nūrını ol ḳıldı vār

Sevdi anı ol Kerīm u Kirdigār

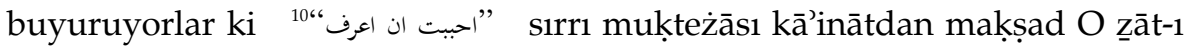
'ālì ve maḥbūb-ı Hudānıñ nūru ve māhiyyet-i Muhammediyyedir, binā'en'aleyh:

Her ne deñlü kim sa'ādet var durur

Yahşī hūy görkli cādet var durur

Haḳ aña virdi mükemmel eyledi

Yāradılmışdan mufażżal eyledi

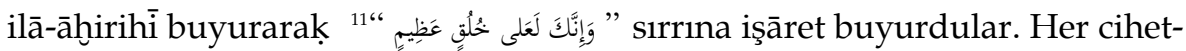
le mükemmel ve cemi' 'i maḩlūḳātdan mufażżal olan ol zāât-1 'ālīniñ şeref ve hürmetine makṣūu bi't-tab` olarak āşikār ve nihān cemí'-i kevn ü mekān huuṣūl-yāfte oldı. Artıḳ ne ḳadar taḳdir-i enbiyā ve mürselīn geldilerse o zāât-1 mübeccele tevessül ederek kiminiñ tövbesi maḳbūl, kiminiñ gemisi onuñ hürmetine garḳdan mașūn ve kimine nār-1 Nemrūd gülşen, kimine 'așā ejder oldu ve kimine de evc-i a'lāya ve semā-yı rūḥa hayyen 'urūc buyurdu. Daha nice mu'cizāt-1 bāhirāt-1 mücerred o zoāt-1 'ālīniñ 'aşk u muhabbeti şerefine vukū' buldı.

Ger Muhammed gelmeyeydi 'āleme

Tāc-1 izzet irmez idi ādeme

[7] buyuruyorlar ki nev'-i ādem ancak o hażretiñ irā'e etdigi meslege ittibā ile maz̧har-1 'izzet olacaḳlarına işāretdir.

Hak Te`āla çün yaratdı ādemi

Ḳıldı ādemle müzeyyen 'ālemi

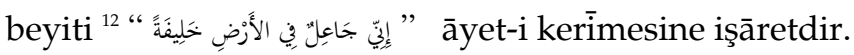

Muștafa nūrını alnında ḳodı

Bil ḥabībim nūrıdır bu nūr didi

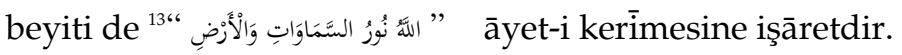

\footnotetext{
${ }^{10}$ Bilinmek istedim. [el-Aclûnî, Keşfü'l-Hafâ, C. II, s. 121]

${ }^{11}$ Ve sen elbette yüce bir ahlâk üzeresin. Kalem/4

${ }^{12}$ Ben yeryüzünde bir halife yaratacağım. Bakara/30

${ }^{13}$ Allah, göklerin ve yerin nûrudur. Nur/35
} 
Șonra Havvā alnına naḳl itdi bil

Ṭurdı anda dahı nice ay $u$ yıl

beyitiyle bu nūr-1 mübārek-i Muhammediyyeniñ Ādem ve Havvā alnında nice zamān ḳaldığını beyān buyurmaları o nūr-ı muḳaddesin şerefi sā'ir benī ādeme de feyż-āver olacag̉ı imā içindir.

Şìt țog̀dı vü ana naḳl itdi nūr

Anuñ alnında tecelli ḳıldı nūr

Geldi çün ol raḥmeten li'l-ālemīn

Vardı [nur] anda ḳarār ḳıldı hemīn

beyitleri devr-i kemālāt-1 Muhammediyyeye işāretdir. Zīrā sa'ādet-i mâddiyye vü ma'neviyyeyi Hażret-i Muhammed 'aleyhi's-salātü ve's-selām bir cem iyyet-i kāmile ile beyān buyurdular idi.

İrdi İbrāhim ü İsmāịile hem

Söz uzanur ger ḳalanın dir isem

İş bu resmile müselsel muttașıl

Tā olınca Mușțafâya müntaḳıl

beyt-i şerīfleri ifāde ediyor ki 'āşıḳ-ı șādık Süleymān Çelebī Hażretleri ecdād-1 hātemü'n-nebiyyîn ḥażretini ta'dād buyurmadılarsa da faḳaṭ: [8]

Tā benī 'Adnāna irdi bā-ṣafā

Tā Ken'āna tā Kureyşe bā-vefā

Çün benī Hāşimde zāhir oldı nūr

Buldı 'Abdü'l-muttalibde key zuhūr

gibi daha nice ebyāt-1 şerīfe Mevlidü'n-Nebī 'aleyhi's-salātü ve's-selāmı istimā'da hāàżr olan ehl-i dil ve 'uşşākẹ resūlullāh ḳaddesallāhu esrārehum ḥażreti tarafından cūş u hưūşa geldikleri eșnāda lisān-ı ḥaḳiḳatlerinden zuhūr etmiş ve ba'zı nüsḩalara da 'ilāve edilmişdir.

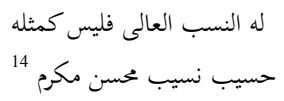

${ }^{14}$ En yüce neseb, Hazret-i Peygamber'indir; onun gibisi yoktur; soyludur, muhsindir ve onur sahibi yüce bir insandır o. [Süleyman Çelebi, Mevlid-i Şerif, Vesiletü'n Necât, [hzl. Mehmet Akkuş-Uğur Derman], Diyanet İşleri Başkanlığı Yay. s. 53] 
Şu na't-1 şerīf ḳadar cenāb-1 Muḥammed 'aleyhi's-ṣalātü ve's-selāmı vāżı̣ ve açık bir șūretde beyān eden na'ta az teșādüf olur. Bu na'atda bi'l-hāạșa şurası tenbīhe şāyāndır ki:

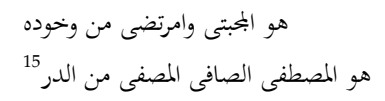

buyuraraḳ cenāb-1 şāh-1 velāyet Hażret-i 'Alì kerremallāhu vechehūnuñ külliyet-i Muhammediyyeye maẓhar oldugunu açık șuretde ifāde ediyorlar.

Āmine Huâtūn Muhammed ānesi

Ol ṣadefden țog̀dı ol dür dānesi

Ma'lūm ola ki burada ve cemi' maḳāmda teşbīhāt-ı a'lāyı ednāya teşbīhdir. Yoḳsa dürr ü șadef vālide-i muḥtereme ve zāât-1 muḳaddes-i Aḥmediyyeye nisbeten hiçbir ḳımeti ve değeri olamaz.

Çünki Abdullāhdan oldı ḥāmile

Vaḳt irişdi hafta vü eyyām ile

Bir hafta yedi günden mürekkeb olub yedi 'adedi ise çok ma'nāsında müsta'meldir. Seb'-i semavāt gibi. Nūr-1 Muhammedīise nice 'așırlar ve biñlerle seneler [9] müstetir ḳaldig̀ gibi baṭn-1 māderde hafta ve eyyām ile vaḳt-i vücūd-1 şerífi yaḳlaşarak 'ālemü'ş-şehādeyi teşrîf buyurdılar.

Ol rebīiül-evvel āyın nicesi

On ikinci gice isneyn gicesi

Rebī'ül-evvelde tevellüdi hayāt-ı 'umūmiyye ma'nāsına işāret, on iki olması

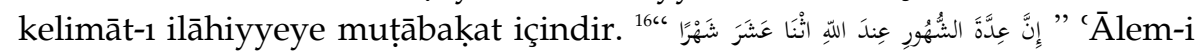
vücūdu gice teşriffleri - zīrā şu ālem-i mâddi ḳarañlıḳdır. - nūr-1 ilāhī olan habīib-i Hudā zulumāt-1 küfrü izāle içün oldugiuna ỉmādır. İsneyn olması zāât-1 pāklarıyla üç olarak cemī'-i ḳāinātda hü̈km-fermā olan hikmet-i ferdiyye-i Muhammediyyeye muvāfı̣̣ bulunmak içün idi.

Didi gördüm ol habīibiñ ānesi

Bir 'aceb nūr kim güneş pervānesi

\footnotetext{
${ }^{15} \mathrm{O}$ varlığıyla kendisinden razı olunmuş ve seçilmiştir. Yine o, incilerden süzülerek seçilmiş tertemiz Mustafa'dır. [Süleyman Çelebi, a.g.e., s. 54]

${ }^{16}$ Allah katında ayların sayısı on ikidir. Tevbe/ 36
} 
Vālide-i muḥtereme ḥażret-i Āmine hạ̄mil oldug̉ı zübde-i kā'inātıñ neş'esiyle hạālet-i istiğrāḳda birçoḳ aḥvāl-i rūhāniyye-i fevḳa'l-ādeyi müşāhede buyurdılar. Ez-cümle şu beyt-i şeriffde ifāde olunduğu vechile nūr-1 Muhammediyyeniñ yanında 'ālemi żiyādār eden güneş nūrsuz pervāne gibi küçük ḳalıyor idi. Naṣıl küçük ḳalmasın ki ḥażret-i müşārünileyhānıñ müşāhede buyurdugiu nūr, nūr-1 ilāhỉ ve hakịịat-1 Muhammediyye idi. Buñā nisbetle ise degil seyyāre-i şems cemí'-i şümūs-1 żiyādār ve nücūm-1 pür-envār hiç degersiz ḳalırlar ve hattā bu nūr-1 muḳaddese ḳarşu pervāne gibi maḥv $u$ helāk bile olurlar. $\mathrm{O}$ nūrdur ki anıñ 'aşḳına bütün seyyārāt devr eder.

Berḳ urub çıḳdı evimden nāgehān

Göklere dek nūr ile toldı cihān

Zaāt-1 ḥażret-i Muhammediyyeniñ mațla'-1 ḥaḳiḳati berḳ gibi çıḳub bütün kā'inātı toldurdu. Lehü'l-ḥamdü ve'l-minne şu yeryüzi zāât-1 hażret-i Muhammediyyeniñ mahall-i ḳudūmu [10] oldugì cihetle ne büyük 'ulviyyet

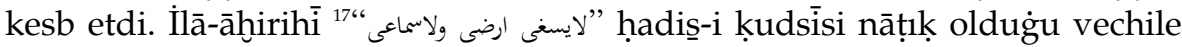
ḳalb-i mü'minde gāyet ufaḳ iken tecelliyāt-ı ilāhiyyeye luṭfen maẓhariyyeti ḥasebiyle şānı şerif ve ḳadri 'āli olmuş idi.

Hem hevā üzre döşendi bir döşek

Adı sündüs döşeyen anı melek

Bu beyt-i şerifde nūr-1 Muhammedī şerefine nev'-i benī ādemiñ nā'il olacağ1 maẓhariyyeti beyān eyler. İnsanlar mehbit-i ilhām-1 ilāhì olan ḳalb u ežhānı ḳuvvetiyle mele'-i 'a'lāya ḳadar teraḳkī edeceklerine işāret idi. Ma'lūm oldugu vechile melek ḳuvve-i ḳudsiyyeden 'ibāretdir.

Üç 'alem dahi dikildi üç yire

Her birisin eydeyim nerden nere

Bu 'alemler ḳuvvet ve zafer ve sancaḳ-1 hạkịḳatdir. Haḳiḳat ise maşrıḳdan ve maġribden ve Kā'betullāhü'l-'ulyādan şeref-z̧uhūr edecegine işāretdir.

İndiler gökden melekler șāf șāf

Ka'be gibi ḳıldılar evim țavāf

Çünki hakikiḳat-i Ka'be de kemālāt-1 Muhammediyyeden oldug̉u cihetle melā'ike-i kirām hāane-i sa'ādeti țavāf idiyor idiler.

${ }^{17}$ Hadis-i şerifden iktibas edilmiştir. 


\section{Yarılub dīvār çıḳdı nāgehān \\ Üç güzel ḥūrī baña oldı 'yyān}

Ol dilberleriñ hażret-i Ḥavvā, Meryem ve Āsiye rażiyallāhu 'anhünneden ibāret olduḳları rivāyet olunuyor ki ilā-āhirihī " hadīṣ-i şerififile medḥ olunmuşlardır. Bu beyt-i şerif de şuña işāretdir ki bu ümmet-i nāciye-i insāniyye terakkiyāt-1 beşer kemālāta yaḳlaşdıḳda bu nisā-ı mübārekeniñ derece-i maz̧hariyyetlerine vāṣıl olacaḳdır ve bu maẓhariyyet de şerīat-1 Mūsā ve Ādem ve 'îsā 'aleyhimü'ṣ-ṣalātü [11] ve's-selāmıñ tamāmī-i zuhūrundan 'ibāretdir. Çünki cem'iyyet-i kāmile-i Muḥammediyye bunı muḳteżīir.

Çevre yanıma gelüb oțurdılar

Muștafâyı birbirine muştılar

Bu beyt-i şerif de kemālāt-1 Muhammediyyeniñ māhiyetini beyāndır ki meselā:

Didiler og̉lūñ gibi hiçbir oġ̀l

Yaradılalı cihān gelmiş degil

beyt-i şerīfi bu hakikịati vāżıhan beyān etmekdedir.

Bu seniñ og̉lūñ gibi ḳadr-i cemīl

Bir anaya virmemişdir ol celīl

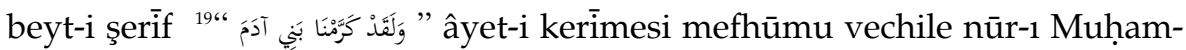
medi devr-i ādemden berü cemāl ü celāl șıfāt-ı subḥāniyyesine maẓhariyyetle mevcūdāta şeref-bahş oldı ise de vālide-i muhteremeniñ nā'il olduḳları şeref ü izzetiñ mevcūdātdan hiç birine müyesser olmadıġını tașriḥ̣dir.

Bu gelen 'ilm-i ledün sulțānıdur

Bu gelen tevhịid ü irfān ḳānıdur

Ulu devlet bulduñ ey dildār sen

Ṭoġisārdur senden ol hulḳ-ı hasen

18 “Erkeklerden bir çok kimse kemâle erdi. Kadınlardan ise Fir'avn'in kadını Âsiye ile İmrân'ın kızı Meryem'den başkası kemâle erişemedi. Bu ümmetin kadınları üzerine Âişe'nin fazîleti de tirid yemeğinin başka yemeklere karşı fazîleti gibidir." Hadisinden iktibas edilmiştir. [Ebû Abdillah Muhammed ibn İsmâil El-Buhârî, Sahîh-i Buhârî ve Tercümesi, [Mütercim: Mehmed Sofuoğlu], C. 7, s. 3218.

${ }^{19}$ Biz, hakikaten insanoğlunu şan ve şeref sahibi kıldık. İsra/70 


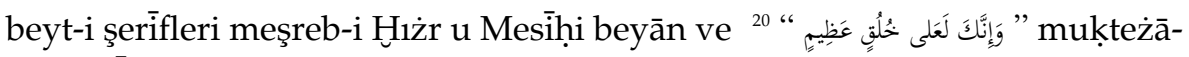
y1 münīfine işāretdir.

Vașfını bu resme tertīb itdiler

Ol mübārek nūrı tergīib itdiler

beyt-i şerifi merātib-i zuhūr-ı Muhammedīniñ edvārını beyāndır. Rabbü̉l'ālemin hạżretleri o nūr-1 muḳaddesi hātemü'n-nebìyyīn hążretlerinde tamāmiyle iẓhār buyurdular. [12]

Āmine eydür çü vaḳt oldı tamām

Kim vücūda gele ol hayru'l-enām

Hangi ḳalemdir ki bu ḳadar büyük ve ateşīn mahabbet ve 'aşḳdan dem uran ebyāt-1 şerīfeniñ tamām ḥaḳịātini beyāna cür'et ede. Vaḳtā ki vālide-i muhtereme-i hayru'l-enāmıñ vaż'-1 hạml etmesi yaḳlaşdı. Fevḳa'l-'āde șusad. Zīrā ḳā'inātı reyyān etmek iḳtidār ve ḳābiliyyeti olan āb-1 hayāt-1 'umūmī kendisinden ayrılacak idi. Buña ise taḥammül olunamayacağı cihetle müşārün-ileyhā haż̇retlerini dehşetli bir ḩarāret istilā etmiş ve bunuñ üzerine feyyāż-1 hakạiḳatden o gevher-i iṣmete bir cām țolusı şerbet iḥsān olunmuşdur. Müşārün-ileyhā her ne ḳadar menba'-1 āb-1 hayayātı 'ālem-i vücūda ị̀sāl ediyorsa da diger țarafdan bu şeref-i 'ālü'l-ālden maḥrūm olmamaḳ içün

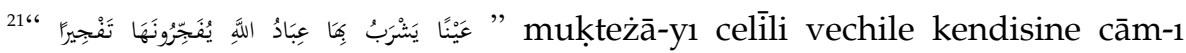
ḥakịiḳat ile şerbet-i Muhammedī vü maḥabbet i'ṭā ve ị̣sān ediliyordu. Görülmez mi ki müşārün-ilāyhā hażretleri anı içdikde vücūd-ı mübārek-i ḥażret-i Āmine nūr-1 maḩ̇z olmuş ve ḥattâ kendilerini nūrdan farḳ edemediler. O eșnāda bir aḳ ḳuş ḳanadı ḳuvvetle zahr-ı Āmineyi șıg̉adı ki bütün ruhāniyyeti ile vuḳū' bulan şu hạāāt-1 fevḳa'l-āde içinde ol sulțānü'lkevneyn 'ālemü'ş-şühedāyı teşríf buyurdılar. Vaż'-1 ḥaml eșnāsında vuḳū's melhūụ olan müşkilāt hiç hiss buyurulmadı. Zīrā ḳuşlar içinde bilhāṣṣa beyāż ḳanad yardım ediyor idi. Seyyidunā Muhammed.

Yaradılmış cümle oldı şādmān

Ġam gidüb 'ālem yeñiden buldı cān

Vilādet-i Muhammediyye vesīle-i celīlesiyle cemīíi mahlūḳāt memnūn oldular. Bu hāa memnūniyyet hāali ve zevkịidir kezāalik cümle zerrāt-1 cihānıñ merḥabā ile istiḳbāli de lisān-1 ḥāli iledir. Ġam gidüb 'ālemiñ yeñiden ḥayāt

\footnotetext{
${ }^{20}$ Ve sen elbette yüce bir ahlâk üzeresin. Kalem/4

${ }^{21} \mathrm{Bu}$ Allah'ın has kullarının içtikleri ve akıttıkça akıttıkları bir pınardır. İnsan/6
} 
bulması şuña işāretdir ki [13] O rūh-1 a'z̧am fahru'l-mürselīn hażzetleriniñ şeref-i ḳudūmındañ muḳaddem rūy-1 zemīn hakịiḳaten bir hạal-i gamnākde idi. Gūyā rūḥsuz cesed gibi olmuşlardı. Çünki ilm-i 'irfān-1 Muhammedī derecesinde maḩ̇̇-1 nūr-1 Hạadan dem uran ḳāmil bir zāāt yeryüzünde ḳalmamış idi. Müşrikīin-i māddiyyīn tamāmıla put-perest olduḳlarından naṣāra-yı ma'neviyyīn yollarını şaşırmışlardı. Haḳiḳaten 'aşk u şevḳ ile "Allāh" diyen yok idi. Fi'l-vāḳi ism-i celīl-i Subḥāniyi żikr edenler çoḳdur faḳaț Süleymān Çelebī hażretleriniñ ta'rífi vechile "Allāh" demege kimiñ isti'dādı vardır? İsm-i 'azāam-ı Subhāniyi öyle söyleyecek lisānda ḥaḳiḳaten büyük isti'dād lāzımdır. Meger ki nūr-1 Muhammedī ile pür-nūr ola. Bināberin zamān-1 tevellüd-i hażret-i nebevīde böyle bir 'āli sulțān ve menba'-1 'urefānñ̃ şeref-ḳudūmu lüzūmu şiddetle teẓāhür etmiş idi. İşte ḩātemü'n-nebiyyīn ve imāmü'l-müttaḳin efendimiz hażretleri ḳadem-nihāde-i 'ālem-i şühūd olaraḳ derdlere dermān olan sırr-1 furḳān-āyāt-1 Kuruānı taḳīir ve 'uşşāḳ-ı ilahīyi lāyık ve müstehạa olduḳları derece-i kemāle ị̣āl buyurdular. áam u ḳasāvet-i küfr gidüb 'ālem yeñiden cān buldı. Bu zāât-1 'āli idi ki İbrāhim 'aleyhi'ṣ-ṣalātü ve's-selāmıñ nesl-i pākinden gelerek ḳurretü'l-'ayn-1

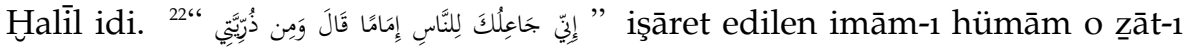
cān-1 cānān hāạṣ̣̂-1 maḥbūb- celīi 'aleyhi'ṣ-ṣalātü ve's-selām idi.

Ey cemâli gün yüzi bedr-i münīr

Ey ḳamu düşmüşlere sen dest-gīr

Cemāl-i Muhammedī güneş gibi parlaḳ vech-i sa'ādeti bedr-i münīr gibi güzel idi. Māh-1 tābān-ı Muhammedīden şu cihetle istifāde olundı. O žāt-1 'āli nice düşkünlere ve biçāregāna dest-gīr oldı. Ve nice nār-1 mahabbetde üftāde olan gurebāyı mevkīíi lāyıḳına iṣāl edüb gerek hür ve gerek bendegāniñ kāffesine melce' oldı. Ya'ni gerek 'alāik-i kevn-i şühūd ile muḳayyed olan bendegān ve gerek cemí'-i kuyūddan āzāde [14] olan hürrriyyetperverānıñ mele’ ve mercı'i ve yegāne hāamīsi oldı.

Ey gönüller derdiniñ dermānı sen

Ey yaradılmışlarıñ sulțānı sen

beyt-i şerífi ifāde eder ki o ḥażret-i fahru'l-mürselīn nice derd-i derūnlarına çāre-sāz olamayan rāh-1 'aşḳda marīż ve bi-çāregāna devā-sāz olub mizāc-1

22 “Bir zamanlar Rabbi İbrahim'i birtakım kelimelerle sınamış, onları tam olarak yerine getirince: 'Ben seni insanlara önder yapacağım.' demişti. 'Soyumdan da önderler yap, yâ Rabbi!' dedi." Bakara/124 nolu ayetten iktibas edilmiştir. 
teb'ine göre tertīb-i 'ilāc eyledi. Bu cihetle cemíc yaradılmışlarıñ sulțānı olmaḳ şerefi o zzāt-ı 'ālìye münḥașır ḳaldı. Bināen-'aleyh cümle enbiyānıñ sulțānı o zāàt-ı 'ālì oldu. Çünki cem'iyyet-i Muhammedìde kāffe-i enbiyānıñ aḥvāl ü ef'āli münderic bulunuyordı ve bütün evliyā ve kāffe-i aṣfiyānıñ nūr-1 çeşmi oldu. Zīiā o zāât-1 āli sebebiyle müşārün-ileyhümanıñ çeşm-i hakịiḳatleri güşāde olaraḳ esrār-1 lāhūt ve hükkm-i melekūta vāḳıf u vāṣıl oldular.

Merḥabā ey māh-1 hưrşīd-i Hudā

Merḥabā ey Ḥaḳdan olmayan cüdā

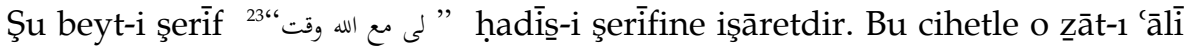
țarīḳ-i hạaḳa hidāyetde şems-i tābān idi.

Ey risālet taḥtıniñ sen hāàtemi

Ey nübüvvet mihriniñ sen hātemi

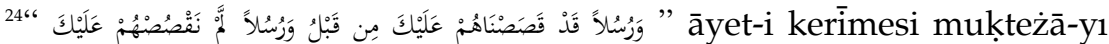
münīfi vechile kāffesinden soñra 'ālemü'ş-şehādeyi teşrîif edüb o zֵāt-1 ma'ālìsimāt tah̆t-1 risāleti cemī' milletiñ sa'ādetini cāmi` olan Ḳur’an-1 kerimi ityān ederek itmām buyurdular. Derece-i nübüvveti de o zzāt-1 'āli temhīr etdi. Bināen'-aleyh bir resūlüñ ba's olmaḳ iḥtimāli ḳalmadı. Faḳaṭ mihr-i nübüvveti rūhāniyyet-i Muhammedī ile her kime temhīr ederse o zāâta derḥāl nübüvvetiñ bir cüz’i olan [15] derece-i velāyet rū-nümā olur.

Çünki ol maḥbūb-1 Raḥmān u Rahīm

Ḳıldı dünyāyı cemālinden na'ìm

O zaāt-ı 'ālì, Raḥmān ve Rahịim șıāteyn-i celīleteynine maẓhar bulundı. O cihetle cemāl-i Muhammedīden bütün dünyā na'im-i cennet oldı.

Birbirine muştulayı her melek

Raḳsa girdi şevḳ u şādından felek

Cemī'-i ḳuvā-yı ḳudsiyye ve ḳāffe-i melekūt-1 rūḥāniyye fevḳa'l-āade memnūn oldı. Çünki o zzāt-1 'āli rūhạnniyyeti gibi cismāniyyeti de tekemmül

\footnotetext{
23 "Benim Allah'la öyle vakitlerim olur ki, o vakitlerde ne bir mukarreb melek ve ne de mürsel bir nebi [hiç kimse] o araya giremez." hadisinden iktibas edilmiştir. [Aclûnî, Keşfü'l-Hafa, C. II, s. 156]

${ }^{24}$ Bir kısım peygamberleri sana daha önce anlattık, bir kısmını ise sana anlatmadık. Nisa/164
} 
etmiş ve mâddeten hem ma'nen aḳ̣ā-yı merātib-i kemālāta vāṣıl olmuşdı. Bu cihetle cemi' melek ve ḳuvā-yı māddiyye ve kāffe-i ecrām-1 'ulviyye hareket ve raḳs edüb iẓhār-1 şevḳ u şādi ediyor idi. Zīiā eflāk-1 'ulviyye ve ecrām-ı semāviyye ve kāffe-i zevi'l- ḥarekātıñ makṣadı o zāât-1 'āli gibi mādden ve ma'nen cā'iz-i kemālāt olmuş žāt-1 şerífi meydāna getirmek ve 'ālemü'ş-şehādeye ișāl ederek sa'yınıñ ve devr-i hareketiniñ semeresini görmek idi. İşte şu șemere-i țayyibe nūr-1 maḥż-1 ḩātemü'n-nebiyyīn 'aleyhi'ṣ-ṣalātü ve's-selām efendimiz ḥażretleriniñ ḳadem-nihāde-i 'ālem-i şühūd olmasıyla ḥuṣūl-pezīir oldı.

İşbu heybetden Āmine hūb-rū

Bir zamān 'aklı gidüb geldi girü

Vālide-i muḥtereme ḥażret-i Āmine şu aḥvāl-i mehābet iştimāli içinde nūr-1 Muḥammedì ḳuvvetiyle müşāhedāt-1 hāariḳu'l-ādāta țalmış idi. Rūḥāniyyet ciheti gāilib olmag̉la bir dürlü ṭ̂fl-1 pāki der-ḩāṭ̂r etmiyor idi. Rūhāniyyetiñ beḳāsı ile berāber o nūr-1 mücessemi hāṭ̂rına getirince cemí'-i hûr u melekden eșer ḳalmayub vālide-i muhtereme hiç kimseyi görmedi. Naṣıl görebilir

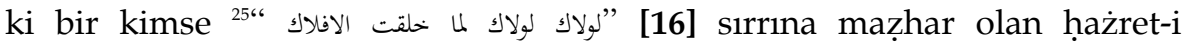
Muhammed 'aleyhi'ș-ṣalātü vesselāma teveccüh ederse hūr-1 cennet ve cemī'-i maḥlūḳātdan eser göremez. Zīrā anlarıñ görünmesi hạkịịat-i Muḥammediyyeye teveccüh edilmedigi hạāldedir. Ve illā hạżret-i faḩr-i kā'inātıñ yanında cemì'-i mükevvenātıñ degeri yoḳ ve belki mefkūid hükmündedir.

Çevre yanıñ isteyü ḳıldı naẓar

Gördi kim bir gūşede hayru'l-beşer

Vālide-i muhtereme, hażret-i ḩayru'l-beşeriñ beşeriyyeti cihetiyle müşāhede buyurdı. Hem de bir köşede gördi. Zīrā anıñ beşeriyyeti bir gūşe-i kāinātda bulunabilir ve faḳaṭ nūrāniyyet-i Muhammedi 'Arş u Kürsīden dahā vāsi' bulunuyor idi.

Debrenür dudaḳları söyler kelām

Añlayamadım ne dirdi ol hümām

${ }^{25}$ Levlâke levlâke lema halaktü'l eflâk. [Eğer Sen olmasaydın varlı̆̆g yaratmazdım.] hadisinden iktibas edilmiştir. [Aclûnî, Keş̧fü'l-Hafa, C. II, s. 148] 
Cenāb-1 fahr-i kāināt 'aleyhi ekmeli't-tahiiyyāt ṭ̂fl iken bir şey’ler söyledigini vālide-i muhtereme hiss buyurdı. Faḳaṭ gāayet hafíf söylüyordı. Bilāhāre añladı ki cān u dilden ümmetini istiyor ve cemì' insanlarıñ raḥmet-i yezdāna mazhhariyyetini ārzū buyuruyordu. Naṣıl ki cenāb-1 'Ĩsā 'aleyhi'ṣ-ṣalātü ve’sselām da țfl iken tekellüm buyurmuşlardı.

Mekke ḳavmi uluları bī-hilāf

Ol gice Ka'beyi ḳılarken țavāf

Kuvve-i Muhammedī ve rūhāniyyet-i Aḥmedī o ḳadar şeref-zuhūr oldu ki o gice Ka'be-i mu'az̧zamayı țavāf eden müşrikīn-i maḥūbīn bile insan-ı kāmiliñ timṣāli olan beyt-i şerífiñ bir țavr-1 mahșūṣ ile secde etdigini müşāhede etdiler. Cemí'i mevcūdāt-1 māddiyye vü ma'neviyyeniñ hayırlısı olan zāat-1 şerīiñ şeref-ḳudūm etdigini Beytullāh-1 'ulyānuñ bi'l-cümle erkānı șalāt u selām ederek haber verdi. Kezālik cihān-1 māddiyyeniñ şemsi bu gice şerefțulū' edüb zulumāt-1 küfr [17] ve cemī' ma'nāsıyla putperestlik çirkābından Ka'betullāhü'l-'ulyānıñ pāk olacaginn sevinerek hạikikat-i Ka'be söyledi üm-

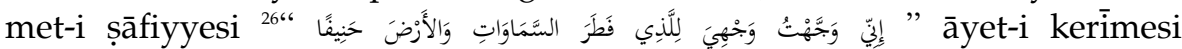
muḳteżāsı hattā Ka'beniñ cihet-i māddiyyesini hāṭ̂ra getirmeyerek ma'nā-yı Ka'beyi ve ḥaḳiḳat-i Beytu'llāhı țavāf ve ta'ẓīm edeceklerdir.

"Kurtarısar beni müşriklerden ol"

mıșrā's buña işāretdir. Cihet-i 'ulüvvün semti olan baş açık yapdılar ki 'ulviyyât u ma'neviyyāt ile münāsebāt u muhāvātları hiçbir mādde-i mug̣āyire mülābis olmayarak füyūżāt-1 ilāhīden şu ümmet-i mübārekeniñ feyż-yāb olacağına işāret ediyordı.

Faḩr-i 'ālem irdi çün ḳırḳ yaşına

Kondı pes tāc-1 nübüvvet başına

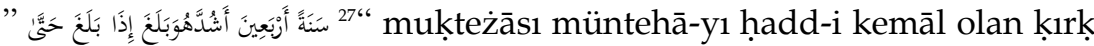
seneye vuṣūlinde o ḥażretiñ ser-i sa'ādetine tāc-1 risālet vaż' edildi. Bu yolda tāc giydirilmek uṣūli cemí'-i enbiyāya ve kāffe-i aṣdıḳ̂ya ve kibār-1 evliyāullāha vuḳū' bulmuşdur. Bu tāc-1 șırf-1 ma'nevī ve emr-i rūhānīir yoḳsa 'ālem-i 'ulvīye nisbetle inci ve elmās ile müzeyyen tāc-1 māddiniñ hîç de degeri yoḳdur.

${ }^{26}$ Ben hanîf olarak yüzümü, gökleri ve yeri yoktan yaratan Allah’a çevirdim. En'âm/79

${ }^{27}$ Nihayet olgunluk çağına gelip kırk yaşına varınca. Ahkâf/15 


\section{İndi Kur'ān āyet āyet beyyināt \\ Zāhir oldı nice dürlü mu'cizāt}

Kur'ān-1 mu'ciz-beyān böyle parça parça şeref-nüzūli isti'dād-1 ümmet nisbetinde hakāyıkııñ keşf ü taḳīirine işāret idi.

Kurān-1 kerīmiñ her āyeti bir mu'cize olmaḳla berāber nice diger mu'cizāt da zāhir oldu. Ma'lūm ile’n-nuhādır ki [18] ḳable'l-bi'ṣe zuhūr eden havārık 'ādāt-ı irhāṣāt ḳabīlinden idi. Mekke ḳavminiñ ve vālide-i muḥteremeniñ müşāhede etdikleri de bu kabīildendir. Ez-cümle mübārek cism-i şerifiniñ gölgesi yere düşmüyor ve bir parça buluṭ re's-i saādeti üzre dāimā țuruyordı. Bu da şuña işāretdir ki şems-i ḥaḳiḳat olan Muhammed 'āleyhi'ṣșalātü ve's-selām ile cesed-i mübārekeleri arasında bir parça buluṭ olmasa hiç kimse nūr-1 Muhammedīye tahammül edemezdi. O parça bulut idi ki

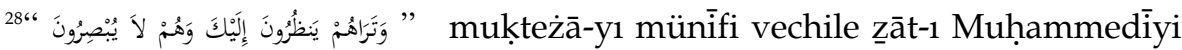
görmegi bir çoḳlara māni oluyordu. Yoḳsa çeşm-i hakịiḳati nūr-1 Muhammedi ile pür-nūr olanlar hem bulutu ve hem de zâat u hakịiḳat-i Muhammedīyi görüyorlardı. Ve hem de o hążretiñ ism-i şerífi nūr idi. Bu 'yyāndır ki nūr içün z̧lll olmaz. Żlll ve gölge zulmānī ve māddī şey’leriñ hāșṣasıdır. Haḳk te âla ve taḳaddes hażretleri habīib-i ekremine nūr ismiyle tecelli et-

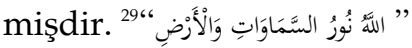

Depredicek dudaġın ol māh-veş

Deprenürdi gökde hem āy u güneş

O żāt-1 'ulüvv-simātıñ dehān-1 mübārekinden kelimāt-1 ilāhiyyeniñ șudūrı āy ve güneşiñ hareketiyle huṣūle gelen tekemmüle benziyordu. Ya'ni şems ve ḳameriñ hareketi kelimāt-1 nebeviyyeye beñziyordı.

Ṭokunicak șaçına bād-1 șabā

Misk üanberle tọlar idi hevā

Bu beyt-i şeriff de o zāât-1 'āliniñ diger mu'cizesine işāretdir. Ya'ni hayayāt-bahşs olan bād-1 ṣabā gibi rūh-1 Muhammedīye nefes edilüb Rūhü̉l-ḳudüs ile mütekellim olan o zāàt-1 āliniñ berekātı ile māddiyyātıñ hafifí olan nesīm-i hevā misk ü 'anber ile toptọolu oluyordı. O hażretiñ māddiyyāt 'āleminden baḥs, tekemmülāt-1 rūhiyyyeye [19] medār olduğı cihetden idi. Bināen-'aleyh būy-1 cāna șafā veren misk ü 'anber o ḥażretiñ māddiyyetden baḥșine beñziyordı.

\footnotetext{
${ }^{28}$ Ve onları sana bakar görürsün, oysa onlar görmezler. A'raf/198

${ }^{29}$ Allah, göklerin ve yerin nûrudur. Nur/35
} 
Bunuñ gibi mübārek șaçına șabā rūzgārı temās etdikde gāyet laṭîf bir rāyiḥa neşr ederdi.

\author{
İncü dişleri şu'āından gice \\ İgne düşse bulunırdı ey hoce
}

Bu beyt-i şerífin de ma'nā-yı mecāzīisi vukū' bulmuşdı. Şöyle ki cenāb-1 seyyidetünā Fāṭımatü'z-zehrā rażıyallāhu 'anhā bir gice dikiş dikerken ignesini gayb etmiş ḥażret-i faḥr-i kā'inātıñ dişleri nūrundan ve şu'ā-1 mübārekinden derḥāl igneyi bulmuş idi. Ma'nā-yı ḥakịịisi ise şöyledir ki bāb-1 ḥakịḳatde ve gice-i māddiyyātda kendine nāfi olan şeyleri gayb edenler kuvve-i Muḥammediyyeye istināden rūhiyyūn olaraḳ şu'ā-1 Muhammedī, māddiyyūn olaraḳ esnān-1 Muhammedì sebebiyle nice tabi'at 'āleminde gààib olan beșeriyyete nāfi bulunan şeyleri bulurlar demekdir.

Șadrı nūrundan ḳarañlık giceler

Yolda yürürdi yigitler ḳocalar

Menba'-1 'ilm ü 'irfān olan șadr-1 pāk-i Muhammedīden leme’ān eden nūr-1 ḥaḳiḳati, hảżret-i 'Alī kerremallāhü vechehu meşrebinde nice yigitler ve Ebū Bekru'ṣ-ṣıddīk rażıyallāhu 'anh meslekinde nice ḳoca iḥtiyārlar görürler, șırāṭ-1 müstakīimde ve țarik-1 tevhīdde kendilerini ta'kịib idenleri selāmete ịsāl ederler demekdir. Ma'lūm ile’n-nuhādır ki ma'nā-yı ḥakịkị șādık olan her mahalde ma'nā-yı mecāzinnıñ isti'māli de lāzım gelmeyecegi cihetle burada cemî́-i ma'nā-yı hakịikịisi şu beyt-i şerífde ol șadr-ı risālete mā-șadak olmuş iken bir de mánā-yı mecāzì ve gāāyet degersiz olan żiyā-yı māddī aramaḳ hātemü'n-nebiyyīn, imāmü'l-muttaḳin hażretlerini görmemezlik

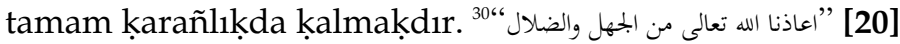

\title{
Terlese güller olurdı terleri
}

Hoş dererlerdi terinden gülleri

Bu beyt-i şerîf de o ḥażret-i 'ālì-şānıñ ma'den-i ḥayā oldug̉unı ifādedir. Çün-

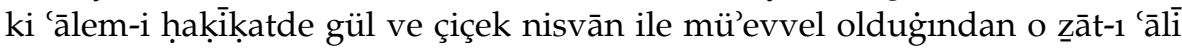
de ḳadınlarıñ hașāil-i memdūḥasından olan hayā șıfatını tahșiș ve zikr ederek her ne vaḳt utanırlarsa kemālāt-ı nisvāndan olan hịlm ve ḥayāsı gül gibi vech-i mübārekinde zāhir olur, azacık terleri rāyiḥa-i gül neşr ederlerdi. Hülāṣa o hażzetiñ nisādan bahişleri haḳịḳaten degerli ve hoş idi. Gül ve çiçek terbiyesince naṣıl ihtimām olunmaḳ lāzım ise reyāḥỉn-i zī-rūh olan

${ }^{30}$ [Cehalet ve sapkınlıktan Yüce Allah'a sı̆̆ınırız.] 
nisvānıñ terbiye ve ta'līmine ihtimām ile tavșiye, o hażretiñ cümle-i kemālinden idi. O cihetle hātemü'n-nebì terlese gül rāyiḥası neşr ediyordu.

Dikdi huurmāyı hem ol şāh-ı cihān

Dikdigi sā'at yemiş virdi hemān

Bu beyt-i şerif ol ḩażretiñ diger mu'cizesini beyāndır çünki nev'i insana pek müşābeheti olan hurma agacını yere diküb derḥāl meyve verdirmesi nev'-i beni ādemde hem māddiyyāt hem mánevīyyāt ile terbiye görür ve 'akl-1 kāmiliñ nezāateti altında bulunursa derḥāl derūnunda merkūz ve meknūz olan kemālātını iẓhār idivirecegine işāret ediyordu. Huurmanıñ her eczāsın-

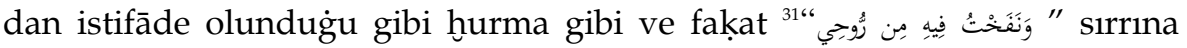
maẓhar olan insanlar hiçbir şey’e ḳıyās ḳabūl etmeyecek derecede maẓhar-1 kemālāt olub bi'l-vücūh şāyān-1 istifāde hāaller kendilerinde zuhūr edecegine işāretdir.

Ger dilersiz bulasız oddan necāt

'Aşk ile derd ile deyüñ eṣ-ṣalāt

beyt-i şerífi irāe eder ki āteşden halāṣ olmaḳ isteyenler 'āşḳ āteşine [21] yanmalıdırlar. Bu da cenāb-1 hātemü’n-nebīyyīn hażretlerine șalāt u selām ve sā’ir vücūh-1 tām ile intisāb ile ḥuṣūl bulur. Cehennem, مريامومن فان نورك نارى أطفأ me'ālinde hadis Āteş-i cehennemi Allāh içün dökülen bir ḳațre gözyaşı itfā' idecegi de ehāāīş-i şerīfede mežkūrdur. O hażrete iştiyāḳen 'aşk ile iftirāḳ-1 Muhammedīye 'adem-i tahammülden hāậl olan derd ile ḳalub 'uşşāḳdan cūş u hurūş ile ber-āverde-i zebān olan șalāt u selām şübhesizdir ki nār-1 cahịimi ve āteş-i firāḳı imḥā ider. Șalavāt-ı şerífeniñ te'širātı mușallīiniñ isti'dādına göredir. Menābi'-i 'ilm ü 'irfān olan enbiyā-yı kirāma șalāt u selām, ḳulūb-1 'uşşāk ile müşārün-ileyhümüñ "șalavātullāh u selāmuhû 'aleyhim ecma'īn" hażarātuna münāsebet ve 'alāḳa ve yekdigere muvāṣāla içündür. Bir nehr-i 'azịimiñ menba'ına muttaṣıl olan bir cedvel, ittiṣāli müddetce cereyān edecegi gibi Süleymān Çelebi gibi āşıke-1 șādıkịiniñ de menba'-1 menābi'-i 'irfān olan rūh-ı Muhammedīye ittiṣāl ü irtibāṭı ḳuvvetli bulundığu cihetle şu eșer-

31 “Onu tamamlayıp içine de ruhumdan üfürdüğüm zaman, derhal ona secdeye kapanın." ayetinden iktibas edilmiştir. Sâd/72

32 "İyi kötü herkes [Cehennem üzerine kurulmuş Sırattan] geçer. İbrahim aleyhisselama ateşin serin olduğu gibi, mümine, serin ve selamet olur. Öyle ki Cehennem, "Müminin nuru nârımı söndürüyor" diye bağırır." hadisinden iktibas edilmiştir. 
i bī-nazịir-i 'ārifānesini müstaciddīn ü erbāb-1 ḥaḳiḳate yādigār buyurub her faṣlıñ 'aḳībinde mežkūr

Ger dilersiz bulasız oddan necāt

beyt-i şerīfini tekrār eylediler. Sālik-i rāh-1 hidāyetiñ misbāḥı olan 'aşḳa tevessül, șalāt u selāma muvāẓabetle hātemü'n-nebīyyīni imāmü'l-müttakịin hażzretlerine taḳarrub olunacaġına işāret buyurdular.

Allāhümme șalli 'alā Muhammedin ve 'alā ālì seyyidinā Muhammed ve Ādem ve Nūh ve İbrāhīm ve Mūsā ve Îsā ve mā-beynehüm mine'n-nebiyyīn ve'l-mürselīn ṣalāvatullāhu ve's-selāmu 'aleyhim ecma'īn.

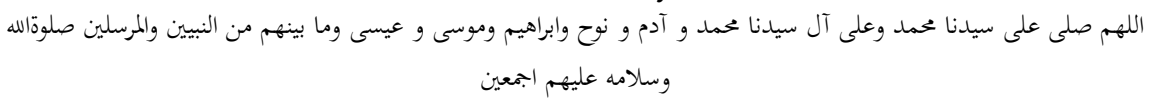

Hātime

Bundan soñra gelen faṣl-1 mi'rāc-1 fahru'l-mürselīn 'aleyhi's-salātü vesselāmıñ şerḥ ve iżāḥına hāāet ḳalmadı çünki ebyāt-ı sābıḳayı minvāl-i muharrer vechile fehm eden ehl-i 'irfān, esrār-1 mi'rācdan burāk ve refrefi, sidretü'l-müntehāda cibrīl ile mükālemeyi mülāḳāt-1 Rabbü'l-ālemīni de fehm etmişdir. Bināen-'aleyh herkes merātib-i 'aḳl u 'ilmine göre nübüvvet ve risāleti idrāk ve ifāde eder. Melāike-i kirāmın kelāmını hikāye bābında

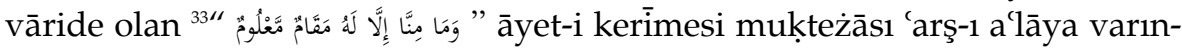
caya ḳadar el elden üstün, herkesiñ ḥaddine göre maḳāmı ya a'lā yā dūndur, faḳat maḳām-1 ḳābe ḳavseyn ev ednāya ${ }^{34}$ vuṣul ḥabīb-i Rabbü̉l-ālemīne mahșūṣdur.

\section{Değerlendirme ve Sonuç}

Hâşim Veli, klasik şerh geleneğine bağlı olarak Mevlid'den seçtiği 61 beyiti açıklamıştır. Yazar, sözü çok fazla uzatmadan beyitin çağrıştırdığı manayı çözmeye çalışmış, bunu yaparken de öncelikle ayet ve hadislere başvurmuştur. Çoğu beyitin arkasından; "āyet-i kerīmesiniñ dahi delālet

\footnotetext{
${ }^{33}$ [Melekler şöyle derler] Bizim her birimiz için, bilinen bir makam vardır. Saffât/164 ${ }^{34}$ "[Peygambere olan mesafesi] iki yay aralı̆̆ kadar yahut daha az oldu." Necm/9 nolu âyetten iktibas edilmiştir.
} 


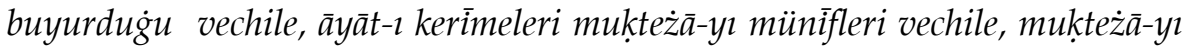
celïlince, ayet-i kerīmesi mefhūmu vechile, mukteż̄a-yı münifine işāretdir" şeklinde sure adı ve ayet numarası belirtmeden Kur'an- 1 Kerim'den bazı iktibaslarda bulunmuştur. Hatta bazı beyitler "āyet-i kerīmesine işāretdir" şeklinde tek bir âyetle açıklanmıştır.

Şerhe konulan hadisleri, hangi hadis âliminden aldığını ve ravîlerini

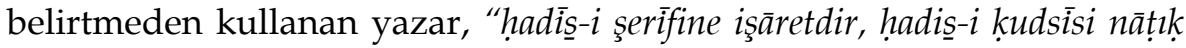

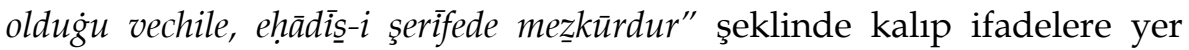
vermek suretiyle hadislerden yararlanmıştır. Bunu yaparken çoğu zaman hadisin anlamını okuyucunun bildiğini düşünerek hadisin tamaminı almamış, bunun yerine anahtar kelimelerle hadise işaret etmiştir. Genel olarak âyetleri de bu şekilde kullanan yazarın bunu bir şerh metodu olarak benimsediği söylenebilir.

Kuran- $\iota$ Kerim'den ve Hz.Peygamber'e ait hadislerden ayrı olup manası yüce Allah'a, ifadesi Hz. Peygamber'e ait olan mübarek sözler olarak kabul edilen kutsi hadislere yer vermek de Hâşim Veli'nin şerhinde başvurduğu bir yol olmuştur.

"Himmet-ür-ricâl, takla'-ül-cibâl [becerikli insanlarm himmeti, dağları yerinden söker], gözlüye gizli yokdur, nūr içün z̧ll olmaz, el elden üstün, söz çok olmağla beraber nihāyet bulmaz" gibi atasözü, deyim veya kelâm-1 kibar kabul edilen kalıplaşmış bazı ifadeler de şerhte kullanılmıştır.

Kelimelerin sözlük anlamlarına zaman zaman başvuran yazarın, kelimenin farklı anlamları üzerinden yorum yaptığı görülmektedir. Örneğin "bari ne" ve "ol" kelimeleri aşağıdaki gibi şerh edilmiştir:

Lisān-1 Türkī'de "bari ne" kelimesi hepsine, mecmū'na, kāffesine demekdir. Ya'ni hāalikiyyet-i subhāaniyyeye dā'ir ḥācet miḳdārı ve kifāyet derece söyleyecek olursaḳ bu bābda söz ve kelām çoḳdur. [...] Yāhūd "bari" kelimesi huulāṣa'-i kelām ma'nāsına olub yine de ma'nā-yı meşrūh melhụuzdur. Binā'en-'āleyh "Birdir Ol kim andan artuk Tañrı yoḳ" buyurarak hatm-i kelām ediyorlar. "Ol" lisān-1 Türkì'de "Hū" ism-i celīliniñ mürādifidir. Çünki “Hüve'l-bākì "dir.

Genel itibarıle bilgilendirmeye yönelik düz bir anlatıma sahip yazarın yer yer klasik inşa kültüründeki sanatsal söyleme yaklaştığ1 da görülmektedir: "kiminiñ tövbesi maḳbūl, kiminiñ gemisi onuñ ḥürmeti- 
ne garḳdan mașūn ve kimine nār-1 Nemrūd gülşen, kimine 'așā ejder oldu ve kimine de evc-i a'lāya ve semā-yı rūḥa hayyen 'urūc buyurdu." Nadir olmakla beraber secili ve süslü bir anlatıma da yer veren yazarın dili Arapça, Farsça kelime ve tamlamalarla örülüdür.

Hâşim Veli, Süleyman Çelebi'ye duyduğu hayranlığını açık bir şekilde ifade eder ve her firsatta övgü dolu sözlerle bu eserin eşsiz olduğunu vurgular:

"Şu na't-1 şerīf ḳadar cenāb-1 Muhammed 'aleyhi's-ṣalātü ve's-selāmı vāżı̣ ve açı bir șūretde beyān eden na'ta az teșādüf olur.", "Hangi ḳalemdir ki bu ḳadar büyük ve ateşin mahabbet ve 'aşḳdan dem uran ebyāt-1 şerīeniñ tamām ḥaḳị̣ātini beyāna cür'et ede."

Tarihî bir olayı anlatmak suretiyle beyitin anlamını açılamak da şerhte başvurulan yollardan biri olmuştur:

"Vaḳtā ki vālide-i muhtereme-i hayru'l-enāmıñ vaż'-1 haml etmesi yaḳlaşdı. Fevḳa'l-āde șusadı. Zīrā ḳā'inātı reyyān etmek iḳtidār ve ḳābiliyyeti olan āb-1 hayāt-1 'umūmī kendisinden ayrılacak idi. Buña ise taḥammül olunamayacaġı cihetle müşārün-ileyhā ḥażretlerini dehşetli bir ḥarāret istilā etmiş ve bunuñ üzerine feyyāż-1 ḥaḳiḳatden o gevher-i 'iṣmete bir cām țolusu şerbet iḥsān olunmuşdur."

Yeri geldikçe peygamberler tarihine göndermeler yapılmış, diğer peygamberlerin belirleyici özelliklerinden ve mucizelerinden hareketle beyitlerle ilişki kurulmuştur:

“Cenāb-1 faḩr-i kāināt 'aleyhi ekmeli't-tahiyyāt ț̣fl iken bir şey’ler söyledigini vālide-i muhtereme hịs buyurdı. Faḳaṭ gāaet hafíf söylüyordı. Bilāhāre añladı ki cān $u$ dilden ümmetini istiyor ve cemīinsanlariñ raḥmet-i yezdāna maẓhariyyetini ārzū buyuruyordu. Naṣıl ki cenāb-1 'İsā 'aleyhi'ṣ-ṣalātü ve's-selām da ṭ̂fl iken tekellüm buyurmuşlard1."

Hâşim Veli, sıcak samimi bir dil kullanmaya özen göstermiş, muhatabını ikna etmede ve inandırıcılığını artırmak için bazı bölümlerde duygu ve heyecanını gizlememiştir:

"[...] melekden eșer ḳalmayub vālide-i muhtereme hiç kimseyi görmedi. Nașıl görebilir ki [...] 
"şu yeryüzi zāatt-1 ḥażret-i Muhammediyyeniñ mahall-i ḳudūmu oldugiu cihetle ne büyük 'ulviyyet kesb etdi."

"Hạạiḳaten 'aşḳ u şevḳ ile "Allāh" diyen yoḳ idi."

"İsm-i 'azām-1 Subḥāniyi öyle söyleyecek lisānda ḥaḳị̣aten büyük isti'dād lāzımdır."

Görünenin ardında daha ulvi bir hakikatin varlığına işaret eden batinî yorumlara Hâşim Veli de yer vermiştir. Batinî yorumların insanların inanç dünyalarına yaptığı gizemli etki düşünüldüğünde hem şairler hem de şârihler makûl ölçüler içinde bu yola başvurmuşlardır:

Şöyle ki cenāb-ı seyyidetünā Fāṭmatü'z-Zehrā rażıyallāhu 'anhā bir gice dikiş dikerken ignesini ġayb etmiş hążret-i faḥr-i kā'inātıñ dişleri nūrundan ve şu'ā-1 mübārekinden derḥāl igneyi bulmuş idi. Ma'nā-yı ḥakịikisi ise şöyledir ki bāb-1 hakịiḳatde ve gice-i māddiyyātda kendine nāfic olan şeyleri ġayb edenler ḳuvve-i Muhammediyyeye istināden rūhiyyūn olarak şu'ā-1 Muhammedī, māddiyyūn olaraḳ esnān-1 Muhạmmedī sebebiyle nice tabi'at 'āleminde ġā’ib olan beşeriyyete nāfic bulunan şeyleri bulurlar demekdir.

Sonuç olarak; Esrâr-ı Mevlidü'n-Nebi'nin klasik şerh yoluyla incelendiğini, uzun dilbilgisi izâhlarına ve tasavvufî ıstılahlara yer verilmediğini, eserin Hz. Peygamber'e ve Süleyman Çelebî'ye son derece hürmetkâr bir tavırla kaleme alındığını belirtmek mümkündür. Yüzyıllar boyu beğenilerek okunan Mevlid'in sahip olduğu değere dikkat çekmesi ayrıca Mevlid'in gizli kalmış bazı yönlerine ışık tutması bakımından bu kısa ve öz şerh önem taşımaktadır.

\section{Kaynakça}

Aclûnî (2007), Keşfü'l Hafa, Dar Al-Kotob Al-Ilmıyah, Beirut-Lebanon.

Aksoy, Hasan, "Mevlid [Türk Edebiyat1]", DİA, (29), s. 482-484.

Canım, Rıdvan, (2010), Divan Edebiyatında Türler, Ankara: Grafiker Yayınları.

Ceylan, Ömür, "Şerh [Türk Edebiyatı]", DİA, (38), s. 565-568. 
Ebû Abdullah Muhammed İbn İsmâil El-Buhârî (1987), Sahîh-i Buhârî ve Tercümesi, [Mütercim: Mehmed Sofuoğlu], C. 7. İstanbul: Ötüken Neşriyat.

Eroğlu, Süleyman (2010), "Edebi Bir Tür Olarak Mevlidler: Şekil Özelliklerine Dair Bazı Değerlendirmeler", Uluslar Arası Mevlid Sempozyumu Bildiriler Kitabı, Ankara: TDV Yayınları.

Çakın, Kâmil (2003), "Kıyamet Alametleri", Dinî Araştırmalar Dergisi, C. 6., Mayıs-Ağustos.

İpekten, Halûk (1997), Eski Türk Edebiyatı Nazım Şekilleri ve Aruz, İstanbul: Dergâh Yayınları.

Köksal, M. Fatih (2009), Mevlid-Nâme Türk Edebiyatında Mevlid Türü ve Yeni Mevlid Metinleri, Kırşehir: Denizoğlu Kitap-Kırtasiye.

Köprülü, M. Fuad (2003), Türk Edebiyatı Tarihi, Ankara: Akçağ Yayınları.

Kuran-ı Kerim ve Açıklamalı Meâli (2010), İstanbul: TDV Yayınları.

Küçük, Murat (2010), "Türk Dünyasından Derlenmiş Bir 'Atalar Sözü' Kitabı", Modern Türklük Araştırmaları Dergisi, 7/1:141-176.

Mazıoğlu, Hasibe (2009), "Türk Edebiyatında Mevlid Yazan Şairler", [Eski Türk Edebiyatı Makaleleri], Ankara: TDK Yayınları.

Pekolcay, Necla, "Mevlid", DİA, (29), s. 485-486.

Süleyman Çelebi (2008), Mevlid-i Şerif, Vesiletü'n Necât, [Haz. Mehmet Akkuş-Uğur Derman], Ankara: Diyanet İşleri Başkanlığı Yayınları.

Şeker, Mehmet, "Mevlid [Osmanlılarda Mevlid Törenleri]", DİA, (29), s. 479480.

Tatçı Mustafa, Musa Yıldız ve Kaplan Üstüner (2006), Mevlid Şerhi Gülzâr-ı Aşk, İstanbul: Dergâh Yayınları.

Timurtaş, Faruk K. (1980), Mevlid-Süleyman Çelebi, İstanbul: Kültür Bakanlığ1 Yayınları.

Yavuz, Kemal (2007), "Mevlid'in Türkçe Kaynakları, Şerhleri ve Mevlid Metni Üzerine", Süleyman Çelebi ve Mevlid Yazılışı, Yayılışı ve Etkileri [Editör: Mustafa Kara-Bilal Kemikli], Bursa: Bursa Osmangazi Belediyesi Yayınları.

Yılmaz, Ozan (2011), Mevlid Şerhi, [Cabbarzâde Mehmed Arif Bey, İzâhü'l Merâm alâ-Vilâdet-i Seyyidi'l-Enâm], İstanbul: Kurtuba Kitap. 